\title{
ANALISIS CAPAIAN INDEKS PEMBANGUNAN KESEHATAN MASYARAKAT PADA INDIKATOR PELAYANAN KESEHATAN DI KABUPATEN TANJUNG JABUNG TIMUR
}

\author{
PUBLIC HEALTH DEVELOPMENT INDEX FOR HEALTH SERVICES \\ IN TANJUNG JABUNG TIMUR \\ Dwi Noerjoedianto ${ }^{{ }^{*}}$, Fitria Eka Putri ${ }^{2}$ \\ 1,2Program Studi Ilmu Kesehatan Masyarakat, Universitas Jambi \\ Jl, Tribata KM 11, Mestong, Muaro Jambi \\ Email : dwi_noerjoedianto@unja.ac.id,
}

\begin{abstract}
In 2013 Public Health Development Index was announced in seven indicators of child health, reproductive health, health services, health protection, non-communicable diseases, infectioous diseases, and environmental health. This research aim to analyzed achievements of public health development index in health service indicators in Tanjung Jabung Timur Regency in 2016-2018. Methodology This was quantitative research. This study was conducted 5 months starting from May to October 2019. Data analyzed used public health development index formula that has been determined by calculating weights for each indicator and then used minimum and maximum standard values. Public health development index indicator values was in the range of 0.1, reversing number 1 indicated an increasing and vice versa. The results and conclusions was the sub-indicators of the health service group in 2016 amounted to 0.504451393 , in 2017 amounted to 0.461817839 and in 2018 amounted to 0.341921748 , this value was questioned in 2016-2018. When compared with the value of the sub-index of health services in Jambi Province, the value of this sub-index is not much different, that is 0.3693. This insurance indicator shows the adequacy of the number of sub-district doctors, the adequacy of the number of posyandu, the adequacy of midwives and the ownership of health insurance for three years in a row under adverse conditions and there must be improvements to increase this value.

Keywords: Public Health Development Index; Health Services
\end{abstract}

\begin{abstract}
ABSTRAK
Tahun 2013 Indeks Pembangunan Kesehatan Masyarakat (IPKM) dijabarkan dalam tujuh kelompok indikator yaitu kesehatan balita, kesehatan reproduksi, pelayanan kesehatan, perilaku kesehatan, penyakit tidak menular, penyakit menular, dan kesehatan lingkungan. Penelitian ini bertujuan secara deskriptif untuk mengetahui gambaran capaian indeks pembangunan kesehatan masyarakat pada indikator pelayanan kesehatan di Kabupaten Tanjung Jabung Timur pada tahun 2016-2018. Metode penelitian ini adalah Jenis penelitian ini adalah penelitian kuantitatif, Penelitian dilaksanakan selama 5 bulan dimulai sejak Mei sampai Oktober 2019. Analisis data menggunakan rumus IPKM yang sudah ditetapkan cara hitungnya dengan menentukan bobot untuk masing-masing indikator lalu menggunakan nilai standar minimal dan maksimal yang telah ditetapkan. Nilai indikator IPKM dalam rentang 0,1, mendekati angka 1 menunjukkan kondisi membaik dan sebaliknya. Hasil dan Kesimpulan adalah nilai sub indeks kelompok indicator pelayanan kesehatan pada tahun 2016 sebesar 0,504451393, tahun 2017 sebesar 0,461817839 dan tahun 2018 sebesar 0,341921748, nilai ini mengalami penurunan dari tahun 2016-2018. Jika dibandingkan dengan nilai subindeks pelayanan kesehatan Provinsi Jambi nilai subindeks tersebut tidak jauh berbeda yaitu sebesar 0,3693. Hal ini ditunjukkan dari kondisi kelompok indikator pelayanan kesehatan yang baik, namun tidak dengan nilai subindeks indikatornya yaitu Kecukupan jumlah dokter perkecamatan, Kecukupan jumlah posyandu, Kecukupan jumlah bidan dan Kepemilikan jaminan pelayanan kesehatan selama tiga tahun berturut-turut memiliki nilai dibawah 0,1 yang artinya dalam kondisi buruk dan harus ada perbaikan untuk meningkatkan nilai tersebut.
\end{abstract}

Kata Kunci: Indeks Pembangunan Kesehatan Masyarakat; Pelayanan Kesehatan 


\section{PENDAHULUAN}

Peringkat

Kabupaten/Kota

dalam

pembangunan kesehatan dapat ditentukan oleh Indeks Pembangunan Kesehatan Masyarakat (IPKM) yaitu indikator komposit yang menggambarkan kemajuan pembangunan kesehatan, dirumuskan dari data kesehatan berbasis komunitas yaitu Riset Kesehatan Dasar (Riskesdas), Survey Sosial Ekonomi Nasional (Susenas), dan Survey Potensi Desa (Podes)(12). Serangkaian indikator kesehatan ini secara langsung maupun tidak langsung dapat berperan meningkatkan umur harapan hidup yang panjang dan sehat. Prinsip umum indikator yang digunakan dalam penyusunan IPKM adalah sederhana, mudah, dapat diukur, bermanfaat, dipercaya, dan tepat waktu. Indikator-indikator terpilih dalam IPKM lebih menunjukkan dampak dari pembangunan kesehatan tahun sebelumnya dan IPKM dapat menjadi acuan pemerintah daerah (Pemda) membuat program intervensi yang lebih tepat, bahan advokasi ke pemda agar terpacu menaikkan peringkat kesehatannya, perumusan daerah bermasalah kesehatan berat/khusus (DBKBK), dasar penentuan alokasi dana bantuan kesehatan dari pusat ke daerah, dan membantu Kementerian Negara Pembangunan Daerah Tertinggal (KNPDT) dalam membangun kab/kota (12).

Provinsi jambi untuk Indeks Pembangunan Kesehatan Masyarakat (IPKM) secara Nasional berada pada urutan 9 dari 33 Provinsi dilihat dari data riskesdas tahun 2013, akan tetapi dilihat dari profil Dinas Kesehatan Provinsi Jambi, masih banyak Kabupaten/Kota dari segi indikator IPKM belum memenuhi target nasional. Keberhasilan pembangunan sektor kesehatan akan mempengaruhi umur harapan hidup. Umur harapan hidup merupakan salah satu indikator menilai indeks pembangunan manusia (IPM). Umur harapan hidup Provinsi Jambi mengalami angka yang fluktuatif dari tahun 2011-2018. Umur harapan hidup Di Provinsi Jambi sebesar 70,71\% (66-76 Tahun) sementara nilai standar minimum penilaian IPKM adalah 100\%. Berdasarkan data Riskesdas tahun 2018 indikator pelayanan kesehatan di Provinsi Jambi mempunyai nilai subindeks terendah dari enam subindeks lainnya yaitu kesehatan balita, kesehatan reproduksi, perilaku kesehatan, penyakit tidak menular, penyakit menular, dan kesehatan lingkungan (16).
Hasil IPKM nasional untuk Provinsi Jambi juga mempunyai nilai terendah pada indikator pelayanan kesehatan. Indikator pelayanan kesehatan secara langsung maupun tidak langsung berperan dalam meningkatkan umur harapan hidup yang panjang dan sehat, IPKM juga digunakan sebagai dasar perencanaan program pembangunan kesehatan di Kabupaten atau Kota dan sebagai bahan pertimbangan untuk memperoleh dana bantuan dari pusat untuk daerah. Indikator pelayanan kesehatan terdiri dari lima 5 sub indikator yang dihitung untuk mendapatkan nilai indikator pelayanan kesehatan tersebut diantaranya Persalinan oleh tenaga kesehatan di fasilitas kesehatan.

Kecukupan jumlah dokter perkecamatan, Kecukupan jumlah posyandu, Kecukupan jumlah bidan, Kepemilikan jaminan pelayanan kesehatan, dari masing-masing sub indikator ini dapat menggambarkan masalah kesehatan yang ditimbulkan dari indikator pelayanan kesehatan12. Data ini menunjukkan bahwa indikator pelayanan kesehatan merupakan masalah kesehatan yang dikategorikan masalah kesehatan berat/khusus berdasarkan perhitungan rata-rata nilai IPKM sehingga perlu untuk di analisis lebih lanjut untuk meningkatkan nilai IPKM pada indikator tersebut dan dapat di cari solusi dalam menanggulangi permasalahan kesehatan pada 5 sub indikator pelayanan kesehatan. Penelitian ini bertujuan secara deskriptif untuk mengetahui gambaran capaian indeks pembangunan kesehatan masyarakat pada indikator pelayanan kesehatan di Kabupaten Tanjung Jabung Timur pada tahun 2016-2018 (7). Oleh sebab itulah peneliti tertarik untuk meneliti "analisis capaian Indeks Pembangunan Kesehatan Masyarakat Pada Indikator Pelayanan Kesehatan di Kabupaten Tanjung Jabung Timur".

\section{BAHAN DAN METODE}

Jenis penelitian ini adalah penelitian kuantitatif. Penelitian akan dilakukan di Kabupaten Tanjung Jabung Timur. Penelitian dilaksanakan selama 5 bulan dimulai sejak Mei sampai Oktober 2019. Pengambilan data dilakukan di Dinas Kesehatan Kabupaten Tanjung Jabung Timur. Subyek penelitian adalah semua data masalah kesehatan yang menjadi indikator pelayanan kesehatan dalam IPKM. Instrumen yang digunakan dalam pengumpulan data penelitian ini dari Daftar 
D. Noerjoedianto dan Fitria Eka. P : Analisis Capaian Indeks Pembangunan Kesehatan Masyarakat Pada Indikator Pelayanan Kesehatan Di Kabupaten Tanjung Jabung Timur

laporan/data yang sesuai dengan indicator dalam sub-indeks IPKM periode Januari 2016-Desember 2018 dan Buku catatan dan alat pencatat. Setelah data terkumpul kemudian dilakukan: Pengolahan data Data yang telah dikumpulkan, editing, selanjutnya dilakukan entri data dengan menggunakan komputer guna pengolahan dan analisis sesuai dengan rumus yang ditentukan.

\section{HASIL DAN PEMBAHASAN}

Hasil penelitian tentang analisis capaian indeks pembangunan kesehatan masyarakat pada indikator pelayanan kesehatan sebagai berikut :

Tabel 1. Hasil Capaian IPKM Pelayanan Kesehatan tahun 2016

\begin{tabular}{lccc}
\hline \multicolumn{1}{c}{ Indikator } & $\begin{array}{c}\text { Sub } \\
\text { Indeks }\end{array}$ & $\begin{array}{c}\text { Sub Indeks } \\
\text { kelompok } \\
\text { Indikator }\end{array}$ & $\begin{array}{c}\text { IPK } \\
\text { M }\end{array}$ \\
\hline Pelayanan Kesehatan & & & \\
$\begin{array}{l}\text { Persalinan oleh } \\
\text { tenaga kesehatan di } \\
\text { fasilitas kesehatan } \\
\text { Kecukupan jumlah } \\
\text { dokter } \\
\text { perkecamatan }\end{array}$ & 0,1838 & 0,504451393 & \\
$\begin{array}{l}\text { Kecukupan jumlah } \\
\text { posyandu }\end{array}$ & 0,055 & & 0,462 \\
$\begin{array}{l}\text { Kecukupan jumlah } \\
\text { bidan }\end{array}$ & 0,0558 & & \\
$\begin{array}{l}\text { Kepemilikan } \\
\text { jaminan pelayanan } \\
\text { kesehatan }\end{array}$ & 0,1324513 & & \\
\hline
\end{tabular}

Tabel 2. Hasil Capaian IPKM Pelayanan Kesehatan tahun 2017

\begin{tabular}{|c|c|c|c|}
\hline Indikator & $\begin{array}{c}\text { Sub } \\
\text { Indeks }\end{array}$ & $\begin{array}{c}\text { Sub } \\
\text { Indeks } \\
\text { kelompok } \\
\text { Indikator }\end{array}$ & IPKM \\
\hline \multicolumn{4}{|c|}{ Pelayanan Kesehatan } \\
\hline $\begin{array}{l}\text { Persalinan } \\
\text { oleh tenaga } \\
\text { kesehatan di } \\
\text { fasilitas } \\
\text { kesehatan }\end{array}$ & 0,1886 & $\begin{array}{c}0,46181783 \\
9\end{array}$ & \\
\hline $\begin{array}{l}\text { Kecukupan } \\
\text { jumlah } \\
\text { dokter } \\
\text { perkecamata } \\
\text { n }\end{array}$ & 0,0365 & & $\begin{array}{l}0,4963228 \\
1\end{array}$ \\
\hline $\begin{array}{l}\text { Kecukupan } \\
\text { jumlah } \\
\text { posyandu }\end{array}$ & 0,0804 & & \\
\hline $\begin{array}{l}\text { Kecukupan } \\
\text { jumlah bidan }\end{array}$ & 0,0573 & & \\
\hline $\begin{array}{l}\text { Kepemilikan } \\
\text { jaminan } \\
\text { pelayanan } \\
\text { kesehatan }\end{array}$ & $\begin{array}{c}0,0990178 \\
4\end{array}$ & & \\
\hline
\end{tabular}

Tabel 3. Hasil Capaian IPKM Pelayanan Kesehatan tahun 2018

\begin{tabular}{|c|c|c|c|}
\hline Indikator & Sub Indeks & $\begin{array}{l}\text { Sub Indeks } \\
\text { kelompok Indikator }\end{array}$ & IPKM \\
\hline \multicolumn{4}{|l|}{ Pelayanan Kesehatan } \\
\hline $\begin{array}{l}\text { Persalinan oleh tenaga kesehatan di } \\
\text { fasilitas kesehatan }\end{array}$ & 0,092 & \multirow{5}{*}{0,341921748} & \multirow{5}{*}{0,5521377} \\
\hline Kecukupan jumlah dokter perkecamatan & 0,038 & & \\
\hline Kecukupan jumlah posyandu & 0,0826 & & \\
\hline Kecukupan jumlah bidan & 0,0558 & & \\
\hline $\begin{array}{l}\text { Kepemilikan jaminan pelayanan } \\
\text { kesehatan }\end{array}$ & 0,07352175 & & \\
\hline $\begin{array}{l}\text { Nilai sub indeks kelompok } \\
\text { pelayanan kesehatan pada tahun } 201 \\
0,504451393 \text {, tahun } 2017 \text { sebesar } 0,46181 \\
\text { tahun } 2018 \text { sebesar } 0,341921748 \text {, nilai ini n } \\
\text { penurunan dari tahun } 2016-2018 \text {. }\end{array}$ & $\begin{array}{l}\text { indikator } \\
6 \text { sebesar } \\
17839 \text { dan } \\
\text { nengalami }\end{array}$ & $\begin{array}{l}\text { Namun untuk sub } \\
\text { jumlah dokter perkecamatan, } \\
\text { posyandu, Kecukupan jum } \\
\text { Kepemilikan jaminan pelayana } \\
\text { tiga tahun berturut-turut memili }\end{array}$ & $\begin{array}{l}\text { deks Kecukupan } \\
\text { ecukupan jumlah } \\
\text { kesehatan selama } \\
\text { nilai dibawah } 0,1 \text {. }\end{array}$ \\
\hline
\end{tabular}




\section{PEMBAHASAN}

\section{Persalinan oleh Tenaga Kesehatan di Fasilitas Kesehatan}

Berdasarkan hasil penelitian diketahui bahwa nilai subindikator persalinan oleh tenaga kesehatan di fasilitas kesehatan mengalami peningkatan nilai dari tahun 2016 ke 2017, namun terjadi penurunan nilai pada tahun 2018. Secara nasional, persentase persalinan yang ditolong oleh tenaga kesehatan terlatih meningkat dari $66,7 \%$ pada tahun 2002 menjadi 77,34\% pada tahun 2009 (Susenas). Angka tersebut meningkat menjadi $82,3 \%$ pada tahun 2010 (8), dan semakin meningkat pada 2013, angka persalinan oleh tenaga kesehatan mencapai 87,1\% (4).

Beberapa faktor yang mempengaruhi rendahnya persalinan yang ditolong oleh tenaga kesehatan di fasilitas kesehatan disebabkan oleh akses kepelayanan kesehatan tersebut(35). Bashur dkk juga menemukan hubungan negative antara jarak dengan ultisi pelayanan kesehatan, makin tidak terjangkau suatu pelayanan kesehatan dasar makin segan mereka datang. Selain jarak tempuh faktor lain yang berpangaruh terhadap persalinan yang di tolong tenaga kesehatan di fasilitas kesehatan adalah tingkat pendapatan dan pendidikan(23).

Berdasarkan teori faktor determinan yang mempengaruhi pertolongan persalinan oleh tenaga kesehatan adalah akses, pendapatan dan pendidikan (24). Jarak sangat membatasi kemampuan dan kemauan seseorang untuk mencari pelayanan atau pertolongan, terutama jika sarana transportasi dan akomodasi terbatas, komunikasi yang sulit dan di daerah tersebut akses kerumah sakit dan pelayanan kesehatan cukup jauh. Ada batas jarak tertentu seseorang mau bepergian untuk mencari pelayanan kesehatan, batas jarak inipun dipengaruhi oleh akses jalan, akses kendaraan, lalu risiko penyakit seseorang dan kemampuan biaya sangat mempengaruhi seseorang pergi kesarana pelayanan kesehatan. Hal inilah yang membuat seseorang yang tidak terjangkau dari dari tenaga kesehatan akan memilih non tenaga kesehatan sebagai penolong persalinan (35).

Pendapatan keluarga dapat mempengaruhi dalam pemanfaatan pelayanan kesehatan dalam hal ini pemilihan tempat persalinan. Pendapatan keluarga merupakan salah satu faktor determinan terhadap akses menuju pelayanan kesehatan.Hal ini menjadi alasan seseorang untuk lebih memilih rumah sebagai tempat persalinan karena mereka beralasan bahwa pemilihan persalinan di rumah lebih sedikit membutuhkan biaya dibandingkan persalinan di fasilitas kesehatan. Mereka menganggap dengan bersalin di rumah bisa menghemat pengeluaran untuk biaya persalinan dan uang persalinan dapat dialihkan untuk membayar jasa tenaga kesehatan. Pendapatan keluarga memengaruhi keluarga dalam membayar pelayanan kesehatan yang dibutuhkan seperti pertolongan persalinan, membeli obat, membayar biaya pelayanan, membayar biaya transportasi ke tempat pelayanan kesehatan dan sebagainya (23). Andersen (1974) menyatakan pendapatan keluarga merupakan karakteristik pendukung yang mempunyai makna bahwa seseorang tidak akan bertindak memanfaatkan pelayanan kesehatan kecuali dia mampu membayarnya. Berdasarkan profil Dinas Kesehatan Kabupaten Tanjung Jabung Timur tahun 2017 tercatat data KK Keluarga miskin di kabupaten tanjung jabung timur tercatat sebesar 63,425\%, hal ini dapat artikan bahwasanya KK dengan keluarga miskin tergolong tinggi (7).

Pendidikan menunjukkan keadaan sosial dari individu atau keluarga. Setiap karakteristik sosial tertentu akan menggambarkan gaya hidup tertentu pula. Sama halnya dengan pemanfaatan pelayanan kesehatan sebagai salah satu gaya hidup yang juga ditentukan oleh karakteristik sosial. Individu yang berpendidikan memiliki kesadaran yang lebih tinggi terhadap pemanfaatan pelayanan kesehatan. Individu terdidik cenderung memiliki pengetahuan yang lebih baik dan memiliki informasi tentang pengobatan medis modern. Pendidikan juga memungkinkan wanita untuk mengambil tanggung jawab pribadi untuk kesehatannya dan kesehatan anak-anaknya (18). Semakin tinggi tingkat pendidikan seseorang semakin banyak informasi yang diperoleh (24). Hal ini sejalan dengan penelitian yang dilakukan oleh Andi Adni Pratiwi et al (2014) bahwa terdapat hubungan yang signifikan antara pendidikan dan pertolongan pelayanan persalinan dengan tenaga kesehatan. Data profil Dinas Kesehatan Kabupaten Tanjung Jabung Timur tahun 2017 tercatat data pendidikan paling banyak ditamatkan penduduk adalah tingkat Sekolah Dasar sebesar 30,23\% dan disusul oleh penduduk yang tidak punya ijazah sekolah dasar sebesar 30,04\% 
sedangkan yang berpendidikan sekolah menengah atas sebesar 13,68\%, hal ini dapat diartikan bahwa tingkat pendidikan penduduk masih tergolong rendah.

\section{Kecukupan Jumlah Dokter per Kecamatan}

Berdasarkan hasil penelitian di atas kecukupan jumlah dokter dari tahun 2016-2018 masih jauh dari angka 1, bahkan di bawah 0,1, yang artinya capaian untuk sub indikator kecukupan jumlah dokter di Kabupaten Tanjung Jabung Timur masih buruk, Apabila jumlah kecukupan dokter melewati angka 0,4 dikatakan cukup dan 1 dikatakan baik atau terpenuhi. Dalam melaksanakan upaya-upaya pembangunan di sektor kesehatan salah satu tanggung-jawab adalah penyediaan sarana dan prasarana pelayanan kesehatan. Sebagai pelaksana upaya kesehatan, diperlukan tenaga kesehatan yang ketersediaannya mencukupi, terdistribusi secara adil dan merata, menguasai kompetensi dan berkinerja prima, sesuai tuntutan kebutuhan pembangunan kesehatan. Dalam Undang-Undang Nomor 17 Tahun 2007 tentang RPJPN disebutkan bahwa tantangan pembangunan bidang kesehatan jangka panjang yang dihadapi antara lain adalah mengurangi kesenjangan status kesehatan masyarakat dan akses terhadap pelayanan kesehatan antar wilayah, tingkat sosial ekonomi, dan gender; meningkatkan jumlah dan penyebaran tenaga kesehatan yang kurang memadai; meningkatkan akses terhadap fasilitas kesehatan; dan mengurangi beban ganda penyakit.

\section{Kecukupan Jumlah Posyandu}

Berdasarkan hasil penelitian diketahui bahwa nilai subindikator kecukupan jumlah posyandu mengalami peningkatan nilai dari tahun 2016-2018, namun angka masih di bawah 0,1 dapat di artikan cakupan posyandu perdesa masih kurang.

Beberapa faktor determinan yang mempengaruhi kecukupan jumlah posyandu antara lain antara partisipasi(29) dan Peran kader (22). Kunci keberhasilan pengembangan program posyandu adalah tumbuhnya partisipasi masyarakat (28). Partisipasi didapatkan dari keaktifan ibu balita datang ke posyandu, hal tersebut dapat dilihat dari motivasi ibu balita untuk datang ke posyandu. Menurut Notoatmodjo (2010)(19), mencari pelayanan kesehatan dapat terwujud dalam tindakan jika hal itu dirasakan sebagai 4 kebutuhan sedangkan kebutuhan merupakan dasar dari terjadinya motivasi. Semakin tinggi motivasi, semakin tinggi intensitas perilakunya. Dengan demikian motivasi yang tinggi untuk membawa balita ke posyandu menjadi rutin, posyandu merupakan sarana kesehatan untuk memantau pertumbuhan dan perkembangan balita sehingga motivasi ibu membawa balita ke posyandu mempengaruhi kunjungan balita ke posyandu19. Hasil ini ada hubungannya dengan data IPKM pada sub indikator balita sangat pendek dan pendek yaitu masih dibawah 0,1 hal ini dapat dikarenakan kurangnya partisipasi ibu datang keposyandu sehingga kurang atau tidak mendapatkan informasi mengenai tumbuh kembang anak yang baik (7).

Faktor lain juga menyebutkan bahwa peran kader dan faktor insentif sangat berpengaruh terhadap berjalannya posyandu. Faktor insentif merupakan salah satu cara meningkatkan kinerja kader posyandu. Jika kegiatan posyandu dimulai, maka kader harus bekerja penuh dari pagi hingga serangkaian kegiatan posyandu selesai. Padahal pada saat kegiatan posyandu para kader harus meninggalkan pekerjaan utama mereka seperti pekerjaan rumah tangga dan pekerjaan lain yang penghasilannya jauh lebih besar. Oleh sebab itu sudah sewajarnya kader posyandu memperoleh insentif sesuai kebutuhan mereka. Ketiadaan dan kurangnya pemberian insentif dalam bentuk uang tunai selalu menjadi alasan penurunan kinerja posyandu. Drop out kader posyandu karena insentif uang yang terlalu kecil, sarana dan prasarana yang kurang serta kurangnya pelatihan (3).

\section{Kecukupan Jumlah Bidan}

Berdasarkan hasil penelitian diketahui bahwa nilai sub indikator kecukupan jumlah bidan pada tahun 2016 ke 2017 mengalami peningkatan sedangkan pada tahun 2018 mengalami sedikit penurunan nilai dan nilai tersebut di bawah 0,1 yang artinya kurangnya cakupan bidan dan nilai tersebut masih buruk, Apabila jumlah kecukupan bidan melewati angka 0,4 dikatakan cukup baik dan 1 dikatakan baik atau terpenuhi.

Permasalahan dalam pemenuhan dan pemerataan tenaga kesehatan kususnya bidan dan dampaknya yaitu formasi terbatas, daerah yang belanja pegawai > $50 \%$ tidak dapat mengusulkan formasi pemda tidak dapat mengangkat tenaga kontrak/honor (PP 48) kecuali BLUD, belum 
berjalannya SI SDMK dan redistribusi sulit dilakukan15. Bidan dinilai sebagai tenaga yang sangat penting dalam penurunan AKI sehingga kualitas dan kuantitas bidan perlu ditingkatkan. Masalah lain yang menyebabkan kurangnya cakupan bidan adalah pemerataan pelayanan kesehatan untuk semua lapisan masyarakat dengan cara penyebaran bidan desa. Banyak bidan yang ditempatkan di daerah terpencil namun itu tidak bertahan lama karena kurangnya fasilitas sarana dan prasarana yang dapat memudahkan kerja bidan. Hal lain juga dipengaruhi ketidaksesuaian gaji dengan beban kerja, karena bidan sudah mau ditempatkan ditempat yang terpencil namun insentif tidak sesuai dengan beban kerja yang mereka dapati. Pendapat yang dikemukakan dalam penelitian Dwi Andiani (2014) faktor sistem merupakan faktor pendukung suatu pekerjaan, bila sarana dan prasarana baik maka proses kerja yang didapatkan juga baik. Artinya bahwa suatu organisasi atau lembaga yang fasilitas sarana dan prasarananya tidak lengkap akan berpengaruh terhadap suatu pelayanan.

\section{Kepemilikan Jaminan Pelayanan Kesehatan}

Berdasarkan hasil penelitian diketahui bahwa nilai subindikator kepemilikan jaminan pelayanan kesehatan mengalami penurunan nilai dari tahun 2016-2018. Kemampuan membayar jaminan kesehatan sangat tergantung pada tingkat pendapatan (27). Kemampuan mereka membayar iuran BPJS (Ability to Pay) sangat dipengaruhi faktor penghasilan dan jumlah tanggungan keluarga dalam rumah tangga. Akses pelayanan kesehatan tidaklah mudah bagi mereka yang berpendapatan rendah (miskin) dan pekerja sektor informal (14). Ada beberapa masyarakat yang mendapatkan bantuan subsidi dari pemerintah terkait jaminan pelayanan kesehatan ini yang disebut juga peserta BPJS penerima bantuan iuran(PBI) namun itu tidak tercover secara keseluruhan untuk masyarakat miskin. Banyak kriteria yang harus dipenuhi untuk mendapatkan BPJS PBI ini, dan apabila masyarakat miskin yang tidak termasuk kriteria dan rekomendasi dari dinas social maka mereka harus membayar iuran setiap bulannya. Hal ini lah yang membuat masyarakat mengurungkan niat untuk ikut menjadi peserta BPJS karena mereka harus menanggung satu keluarga dengan pendapatan yang tidak seberapa. Data KK di kabupaten tanjung jabung timur tercatat sebesar $63,425 \%$ terdiri dari keluarga miskin, hal ini dapat menjadi tolak ukur kenapa nilai pada indikator ini masih buruk.

\section{KESIMPULAN}

Nilai indikator pelayanan kesehatan mengalami penurunan selama tiga tahun yaitu pada tahun 2016 sebesar 0.5 yang artinya sudah cukup baik, pada tahun 2017 turun menjadi 0,4 yang artinya cukup baik namun pada tahun 2018 kembali mengalami penurunan nilai menjadi 0.3 yang artinya bermasalah dan harus segera diperbaiki. Pada nilai lima sub indikator pelayanan kesehatan terdiri dari persalinan oleh tenaga kesehatan, kecukupan jumlah dokter perkecamatan, kecukupan jumlah posyandu, kecukupan jumlah bidan dan kepemilikan jumlah pelayanan kesehatan dari tahun 2016-2018 nilai selalu dibawah 0,4 yang berarti indikator pelayanan kesehatan yang memiliki masalah cukup serius sehingga masih perlu dikaji lagi satu persatu agar dapat di jadikan sebagai bahan untuk perbaikan untuk membuat suatu kebijakan yang tepat di tahun yang akan dating

\section{DAFTAR PUSTAKA}

1.Arsunan, A. A. (2012) 'Epidemiologi Penyakit TIdak Menular', Buletin Jendela Data dan Informasi Kesehatan. doi: ISSN 2088-270X.

2.Andi A. P., Balqis, M. Yusra (2014). Faktor Yang Berhubungan Dengan Pemanfaatan Pertolongan Persalinan Oleh Tenaga Kesehatan Di Wilayah Kerja Puskesmas Barebbo Kabupaten Bone.Jurnal Universitas hassanudin

3.Bhattacharyya, K., Winch, P., Leban, K. \& Tien, M. 2001. Community Health Worker Incentives and Disincentives: How Th ey Aff ect Motivation, Retention, and Sustainability. Arlington, Virginia: Basic Support for Institutionalizing Child Survival Project (BASIC II). Th e United State Agency for International Development

4.Badan Penelitian dan Pengembangan Kesehatan. (2014) Indeks Pembangunan Kesehatan Masyarakat. Edited by Editor Trihono dan Sudomo. Jakarta.

5.Badan Penelitian Dan Pengembangan Kesehatan Kementerian Kesehatan RI (2013) Riset Kesehatan Dasar 2013, Kementrian Kesehatan Republik Indonesia. doi: 1 Desember 2013.

6.Badan Pusat Statistik (2016) 'Indeks Pembangunan Manusia 2015', Badan Pusat Statistik. doi: 
D. Noerjoedianto dan Fitria Eka. P : Analisis Capaian Indeks Pembangunan Kesehatan Masyarakat Pada Indikator Pelayanan Kesehatan Di Kabupaten Tanjung Jabung Timur

10.1371/journal.pone.0144713.

7.Dinas Kesehatan Provinsi Jambi (2017) profil Dinas Kesehatan Provinsi Jambi. Jamb.

8.Hernawati I. Analisis Kematian Ibu Di Indonesia

Tahun 2010 Berdasarkan Data SDKI,

Riskesdas dan laporan rutin KIA.

Online) diunduh; 2011.

9.Indonesia, K. K. R. (2018) Profile Kesehatan Indonesia Tahun 2017, kementerian Kesehatan. doi: 10.1002/qj.

10.Iswarawanti DN (2010) Kader Posyandu: Peranan dan Tantangan Pemberdayaannya Dalam Usaha Peningkatan Gizi Anak di Indonesia, Universitas Indonesia, 169-173

11.KemenKes R.I. Ayo Ke Posyandu Setiap Bulan Posyandu Menjaga Anak Dan Ibu Tetap Sehat. Jakarta: Kementerian Kesehatan R.I, Pusat Promosi Kesehatan; 2012

12.Kemenkes RI (2010) Indeks Pembangunan Kesehatan Masyarakat 2010, Kementrian Kesehatan RI. doi: 10.1007/s11595-010-2328-5.

13.Kemenkes RI (2012) 'Petunjuk Teknis Pos Pembinaan Terpadu Penyakit Tidak Menular (POSBINDU PTM)', Kementerian kesehatan RI. doi: ISSN 2088-270X.

14.Kementerian Kesehatan (2016) ‘Peraturan Menteri Kesehatan Republik Indonesia Nomor 43 Tahun 2016 Tentang Standar Pelayanan Minimal Bidang Kesehatan', PERATURAN MENTERI KESEHATAN REPUBLIK INDONESIA NOMOR 43 TAHUN 2016 TENTANG STANDAR PELAYANAN MINIMAL BIDANG KESEHATAN. doi: 10.1016/j.spinee.2015.04.027.

15.Kementerian Kesehatan RI (2017) Data dan Informasi Profil Kesehatan Indonesia 2016, Kementerian Kesehatan RI. doi: http://dx.doi.org/10.1007/BF00571410.

16.Kementerian Kesehatan RI (2018) 'Hasil Utama RISKESDAS 2018', Development. doi: 10.1109/ISC2.2016.7580753.

17.Kementrian Kesehatan RI (2016) Pusat Data Dan Informasi Kementerian Kesehatan RI, Situasi Balita Pendek. doi: 10.1017/CBO9781107415324.004.

18.Kristiani, S 2009, 'Socio Economic and Demographic Determinants of Maternal Health Care Utilization Indonesia' Thesis, The Flinders University of South Australia. Adelaide.

19.Notoatmodjo. (2010). Ilmu Perilaku Kesehatan. Jakarta: Rineka Cipta.

20.Maine, D, 1993, Safe Motherhood Programs:
Options and Issues, Center for Population and Family Health, New York.

21.MCA-Indonesia and Kesehatan, K. R. I. (2015) Pedoman Pelaksanaan Sanitasi Total Berbasis Masyarakat, Millennium Challenge A ccount Indonesia.

22.Muzakkir (2013) Faktor-faktor yang berhubungan dengan kinerja kader posyandu di wilayah kerja UPTD puskesmas Kaledupa Kecamatan Kaledupa Sulawesi Tenggara, V01.2:2, ISSN 2302-1721

23.Putri, Meivy D (2016) faktor-faktor yang Berhubungan dengan Pemilihan Tempat Persalinan Tahun 2015, Jurnal Kesehatan Masyarakat. Vol.4:2, ISSN:2356-3346

24.Notoatmojo, S. (2007) Promosi Kesehatan dan Ilmu Perilaku, Buku. doi: 10.1016/j.athoracsur.2009.02.081.

25.Nur sholichah, nanik puji lestari (2017) 'Asuhan Kebidanan Komprehensif pada Ny. Y (Hamil, Bersalin, Nifas, BBL, dan KB)', Jurnal Komunikasi Kesehatan.

26.Pratiknya, A. W. (2003) Dasar Metodologi Penelitian Kedokteran \& Kesehatan. Jakarta: PT. Raja Grafindo Persada.

27.Rasyid, R., Mayulu, N. and Kandou, G. D. (2006) ‘Hubungan Karakteristik Balita, Penyakit Infeksi dengan Status Gizi pada Anak Balita di Wilayah Kerja Puskesmas Gambesi Kota Ternate', Jurnal Kesmas FKM Unsrat. doi: 10.1002 /zaac. 200500504.

28.Syafrudin. (2009). Buku Ajar Ilmu Kesehatan Masyarakat untuk Mahasiswa Kebidanan. Jakarta: CV Trans Info Media.

29.Subagyo widio, Mukhadiono (2010) Kemampuan Kader dan Partisipasi Masyarakat Pada Pelaksanaan Program Posyandu di Karangpucung Purwokerto Selatan Kabupaten Banyumas, Jurnal Keperawatan Soedirman), Vol.5: 2.

30.Sugiono (2004) Statistik untuk Penelitian. Bandung: CV. Alfabeta.

31.Sukarto, R. C. W. et al. (2016) 'Suhu, Kelembaban dan Pencahayaan sebagai Faktor Risiko Kejadian Penyakit ISPA pada Balita di Kecamatan Balaesang Kabupaten Donggala', Jurnal Berkala Epidemiologi. doi: 10.1111/ijlh.12426.

32.Unicef (2012) 'Kesehatan Ibu \& Anak', UNICEF Indonesia. doi: 9870. 
D. Noerjoedianto dan Fitria Eka. P : Analisis Capaian Indeks Pembangunan Kesehatan Masyarakat Pada Indikator Pelayanan Kesehatan Di Kabupaten Tanjung Jabung Timur

33.WHO - World Health Organization (2017) World Health Statistics 2017: Monitoring Health for The SDGs, World Health Organization. doi: 10.1017/СВO9781107415324.004.

34.WHO ICM \& FIGO. Making Pregnancy Safer: The Critical Role of The Skilled Attendant: A Joint Statement by WHO, ICM and FIGO. Geneva: WHO. 2004. 11. World Health Organization. Making Preganancy Safer: Skilled Birth Attendants. Geneva; 2008.

35.Wulansari Neni, Anita Dwi (2011) Hubungan Antara Status Ekonomi dan Jarak Tempuh Pada Ibu Hamil dengan Pemilihan Penolong Persalinan di Desa Ngendrikilo Magelang, Jurna Kebidanan, Vol.III:1 